\title{
Structure and biodiversity of zooplankton communities in freshwater habitats of a Vereda Wetland Region, Minas Gerais, Brazil
}

\author{
Estrutura e biodiversidade de comunidades zooplanctônicas em habitats de \\ água doce de uma Região de Vereda, Minas Gerais, Brasil
}

Olívia Penatti Pinese ${ }^{1}$, José Fernando Pinese ${ }^{1}$ and Kleber Del Claro ${ }^{2}$

\author{
${ }^{1}$ Programa de Pós-graduação em Ecologia e Conservação dos Recursos Naturais, \\ Laboratório de Zoologia, Instituto de Biologia, Universidade Federal de Uberlândia - UFU, \\ Campus Umuarama, Bloco 2D, CEP 38400-902, Uberlândia, MG, Brazil \\ e-mail: oliviapp@gmail.com; jfpinese@gmail.com
}

${ }^{2}$ Programa de Pós-graduação em Ecologia e Conservação dos Recursos Naturais, Laboratório de Ecologia Comportamental e de Interaçóes, Instituto de Biologia, Universidade Federal de Uberlândia - UFU, Campus Umuarama, Bloco 2D, CEP 38400-902, Uberlândia, MG, Brazil e-mail: delclaro@ufu.br

\begin{abstract}
Aims: Vereda wetlands are among the most important aquatic habitats in Brazilian savannah (Cerrado) because of their association with river springs and its relevancy for biodiversity conservation. This study aimed to determine and compare the biodiversity of zooplankton in vereda lakes, differentiated by the presence or absence of aquatic macrophytes at an environmental reserve in Uberlândia, Minas Geais, Southeastern Brazil. Zooplanctonic abundance patterns and their relation with environmental parameters were also discussed and presented through multivariate statistics. Methods: Twelve samples were taken at water surface, at 15-day intervals in 2006. It was observed a total richness of 75 species, including 12 genera, 29 species and one sub-species as new records for Minas Gerais State. Results: Rotifers were the predominant group and Lecanidae was the most diverse family. Among cladocerans, Chydoridae showed the greatest richness and Bosminidae the highest abundance. Few adult copepods were sampled in this study, but nauplii were very frequent. Cyclopidae was the most common family among copepods and there was no record of Calanoida. Conclusion: The difference in composition among the studied lakes was remarkable. The lake with macrophytes showed the greatest richness but the lowest density, and the opposite situation occurred in the other lake. This can be explained by the fact that aquatic macrophytes, as primary producers, exert a bottom-up effect on zooplankton community, sustaining a high local diversity in contrast with a low numeric abundance of these microorganisms. Therefore, this pattern may have been created by the surround heterogeneity and, at the same time, by the reduction of available minerals of the system caused by macrophyte matter fixation. Many studies on zooplankton need to be developed in palm swamp communities in order to better comprehend the biological diversity and the energy balance in different habitats for the conservation of aquatic ecosystems.
\end{abstract}

Keywords: freshwater zooplankton; veredas; Copepoda; Cladocera; Rotifera.

Resumo: Objetivo: Veredas estáo dentre os mais importantes habitats aquáticos do cerrado brasileiro por estarem associados a nascentes de rios e por sua relevância para a conservação da biodiversidade. Os objetivos deste estudo foram determinar e comparar a biodiversidade zooplanctônica em lagos de veredas distintos pela presença/ausência de macrófitas em uma reserva ambiental em Uberlândia, MG, Sudeste do Brasil. Padrôes de abundância zooplanctônica e suas relaçóes com variáveis ambientais também foram discutidos e apresentados por meio de estatísticas multivariadas. Métodos: Em 2006, foram realizadas 12 coletas de superfície quinzenalmente. A riqueza total observada foi de 75 espécies, das quais 12 gêneros, 29 espécies e uma subespécie constituem novos registros para o Estado de Minas Gerais. Resultados: Os rotíferos representaram o grupo predominante ( $75 \%$ das espécies) e Lecanidae foi a família mais diversa. Dentre os cladóceros, Chydoridae destacou-se em riqueza e Bosminidae em abundância. Poucos copépodos adultos foram amostrados, mas náuplios foram frequentes. Cyclopidae 
foi a família de maior ocorrência para este grupo e não houve registro de Calanoida. Conclusóes: Houve diferença notável entre a composição dos lagos. O lago com macrófitas apresentou elevada riqueza e baixa densidade e a situação contrária ocorreu no lago aberto. Isto pode ser explicado pelo fato de que as macrófitas aquáticas, como produtores primários, exercem efeito bottom-up na comunidade do zooplâncton, sustentando uma elevada diversidade local em contraste com uma reduzida abundância numérica desses microrganismos. Este padrão pode então ser gerado pela heterogeneidade ambiental do entorno e, ao mesmo tempo, pela redução de minerais disponíveis no sistema através da fixação de matéria ocasionada por esses vegetais. Muitos estudos sobre o zooplâncton precisam ainda ser desenvolvidos em comunidades de veredas no Brasil a fim de melhor compreender a diversidade biológica e o balanço energético em diferentes hábitats, visando a conservação de ecossistemas aquáticos.

Palavras-chave: zooplâncton de água doce; veredas; Copepoda; Cladocera; Rotifera.

\section{Introduction}

In many lakes of vereda wetlands in Brazilian savannah (Cerrado), banks of aquatic macrophytes are very frequent. In aquatic ecosystems, these plants can be compared to terrestrial forests, increasing productivity and diversity, elevating the availability of trophic resources, creating thermal comfort and lower brightened areas, and providing shelter to a rich variety of fishes and aquatic invertebrates (Esteves \& Camargo, 1986). Because of these environmental values of the vereda wetlands, many efforts have been made to preserve and restore them (Björk, 2010). Among the most important organisms in veredas, it can be highlighted the plankton, a community related with autochthonous productivity and energy flow in lentic environments. Very typical planktonic groups may occur in habitats overgrown by macrophytes, with adaptations to the particular conditions created by these plants (Santos-Wisniewski et al., 2002).

Studies on aquatic environments overgrown by macrophytes have focused mainly on taxonomic aspects, emphasizing plants themselves, periphyton and fishes (Casatti et al., 2003; Bini et al., 2005; Taniguchi et al., 2005). Several researches on freshwater zooplankton community have been conducted in Brazil, but despite its great ecological importance, little attention has been given to the zooplankton studies in vereda ecosystems, only became more significant from 2000 (Lima et al., 2003, Maia-Barbosa et al. 2008; Peixoto et al., 2008; Pinese et al., 2008; Lansac-Tôha et al., 2009, Colares et al., 2013).

The macrophytes are responsible for great part of the productivity that sustains food chains in lentic environments of veredas, whether natural or artificial. They change in different ways the dynamics of these ecosystems, also contributing to stability in ecological relationships and in community trophic links (Esteves, 2011). Besides causing an increase in habitat heterogeneity, the macrophytes also increase the availability of food resources, thermal comfort and areas of lower brightness in this region (Esteves \& Camargo, 1986). As proposed by Niche Theory (Grinnell, 1917), different habitats and local environmental conditions favor survival and reproduction of different species in the ecosystems. For this reason, it was hypothesized that the particular environmental conditions of the lakes covered by aquatic macrophytes as well as its higher habitat heterogeneity are determinant of a great variation in both abiotic and biotic components of the ecosystem, which increases local diversity of zooplankton in its surroundings. So, the main objective was to demonstrate and compare the composition (richness and density) of zooplankton (Copepoda, Cladocera and Rotifera) between two vereda lakes differed by the presence or absence of aquatic macrophytes, in Uberlândia, Minas Gerais, Southeastern Brazil, and therefore confirm the hypothesis that zooplankton biodiversity is higher in the lake covered by these plants. Furthermore, this work aimed to correlate a set of physical-chemical parameters of each lake with the biological variables (zooplankton richness).

\section{Material and Methods}

The survey was conducted in two vereda lakes located in the Private Natural Heritage Reserve of the Clube Caça e Pesca Itororó de Uberlândia (CCPIU), Minas Gerais, Southeastern Brazil (185' $51^{\prime \prime}$ S, 4817'27' W; Figure 1). The artificial lakes were built in 1970, at Cabeceira do Lageado Stream, Paraná River Basin, and mainly differ by the presence of macrophytes (predominantly Pontederia parviflora and Heteranthera sp., Pontederiaceae) and little depth in the first one (Lake I; depth $=3.5 \mathrm{~m}$ ); and absence of macrophytes and a higher depth in the other (Lake II; depth $=5.0 \mathrm{~m}$ ). 

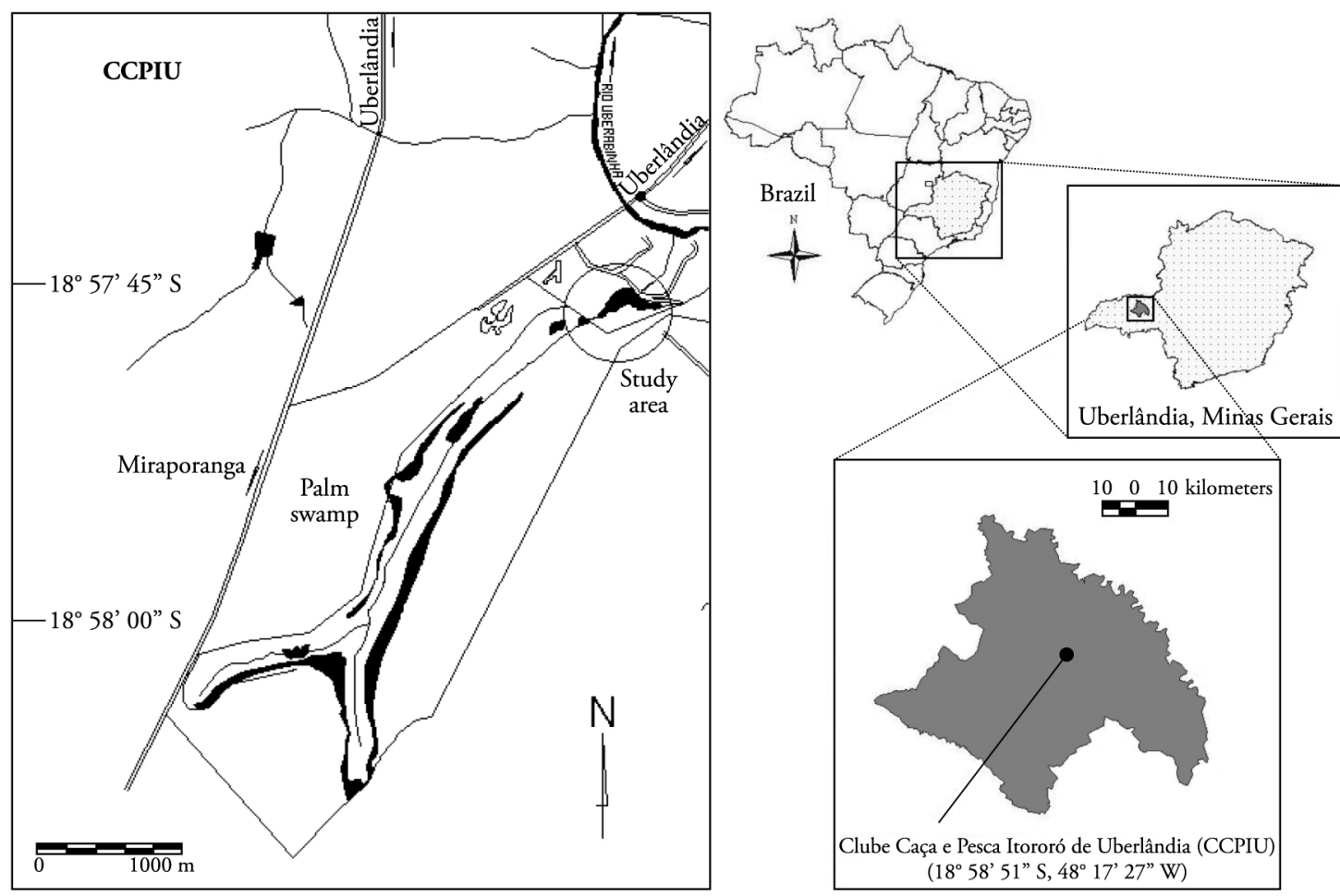

Figure 1. Natural Reserve of Clube Caça e Pesca Itororó de Uberlândia (CCPIU) and the location of the study area.

Köppen (1948) classifies the Uberlândia climate as tropical altitude with hot summer (Cwa), characterized by two well-defined seasons: rainy summer (October to March) and dry winter (April to September). Annual average temperature varies between $18^{\circ} \mathrm{C}$ and $24^{\circ} \mathrm{C}$, and annual average precipitation is around $1,707 \mathrm{~mm}$ (Del-Grossi, 1993). The CCPIU Natural Reserve has a total area of 640 ha, with cerrado stricto sensu as predominant vegetation, which includes a vereda of 127 ha, characterized by the presence of Mauritia flexuosa L.f. palm tree (buriti) (Appolinario \& Schiavini, 2002; Araújo et al., 2002).

From July to December 2006, water samples were collected at 15 day intervals, with two collections per month (A and B). For quantitative samples, an "Instant Collector" with 10 L capacity was applied at sub-surface to collect $50 \mathrm{~L}$ of water (Pinese et. al., 2008), which was filtered in a $17 \mu \mathrm{m}$ net and preserved in 95\% ethyl alcohol (Hall, 1964; Black \& Dodson, 2003; Pinto-Coelho, 2004). Qualitative samples were taken by washing leaves of macrophytes and filtering the material at a $70 \mu \mathrm{m}$ net, and through horizontal and vertical dragging with a $70 \mu \mathrm{m}$ plankton net. Larger meshes in qualitative samples in respect of qualitative were used in order to minimize obstruction of the net, since in this moment of the sample a larger volume of water was filtered. The water transparency, temperature, $\mathrm{pH}$, electrical conductivity and dissolved oxygen were measured using Secchi Disk, Handylab-1 (Schott) and Microprocessor Oximeter SL520 (Solar Instrumentation) equipment.

All individuals from quantitative samples (rotifers, copepods and cladocerans) were quantified and identified under stereomicroscopy and microscopy. Also, stage of copepods were determined. The qualitative samples were analyzed on the same way, but the organisms were not quantified. Specialized species keys were used for identification (Rocha \& Matsumura-Tundisi, 1976; Koste, 1978; Pontin, 1978; Matsumura-Tundisi \& Rocha, 1983; Reid, 1985; Matsumura-Tundisi, 1986; Silva et al., 1989; Korovchinsky, 1992; Dussart \& Defaye, 1995; Segers, 1995; Morales et al., 1996; Smirnov, 1996; Elmoor-Loureiro, 1997; Smirnov, 1998; Korinek, 1999; Jersabek et al., 2007; Sinev \& Elmoor-Loureiro, 2010). The samples of zooplankton are currently held in the Museu de Biodiversidade do Cerrado, Universidade Federal de Uberlândia.

To characterize the community structure, numerical density (ind. $\mathrm{m}^{-3}$ ) was determined, as well as relative abundance, richness $(\mathrm{S})$, diversity indexes (Shannon-Wiener: $\mathrm{H}^{\prime}=-\sum \mathrm{p}_{\mathrm{i}} \log _{2} \mathrm{p}_{\mathrm{i}}$; and Simpson: $\left.\mathrm{D}^{\prime}=1-\sum(\mathrm{pi})^{2}\right)$ and evenness (Pielou index: $\mathrm{J}=\frac{\mathrm{H}^{\prime}}{\log _{2} \mathrm{~S}}$ ) 
(Pielou, 1998). A t-Student test was applied (95\% confidence interval) to compare environmental data, indexes of diversity and abundances between wet and dry seasons. The normality was tested for these data sets (Zar, 1999) using Systat 10.2 (Systat, 2002). Species accumulation curves were constructed to estimate total richness using EstimateS 7.5, and four estimators were calculated: Cole, Ace, Jack 1 and Chao 1 (Colwell, 2005). A canonical correlation analysis (CCA) was applied in order to graphically correlate the multidimensional variation of a set of environmental and biological variables (Ter Braak, 1986, 1988, 1995). Environmental data were standardized and 999 permutations were applied for this. A cluster analysis was applied to group similar samples using average linkage method (UPGMA) and Bray-Curtis index to abundance data, using Fitopac 1.6 (Shepherd, 1996).

\section{Results}

During the sampled period, the coldest and driest month was July $\left(20.4^{\circ} \mathrm{C}\right.$; $\left.0 \mathrm{~mm}\right)$ and the hottest and rainiest month was December $\left(23.5^{\circ} \mathrm{C}\right.$; $460.4 \mathrm{~mm}$ ) (Figure 2). Water transparency has changed only in Lake II, with Secchi values ranging from $1.20 \mathrm{~m}$ (Oct B) to $3.10 \mathrm{~m}$ (Dec B). In Lake I, water was crystalline at all samples. Water temperature on surface (Table 1) increased during the study period with lower values in Lake I (average $=19.9^{\circ} \mathrm{C}$ ) than in Lake II (average $\left.23.1^{\circ} \mathrm{C}\right)(\mathrm{p}<0.05)$. There was a slight decrease in oxygenation during warmest months in both lakes. In Lake I, the values of dissolved oxygen ranged from 2.13 to $5.11 \mathrm{ppm}$, and in Lake II, the variation was from 4.15 to $7.68 \mathrm{ppm}$ (difference of $2.28 \mathrm{ppm}$ in average; $\mathrm{p}<0.001)$. The $\mathrm{pH}$ in both lakes was below neutrality (7.00) and remained slightly acid in all samples. In Lake I, the values of

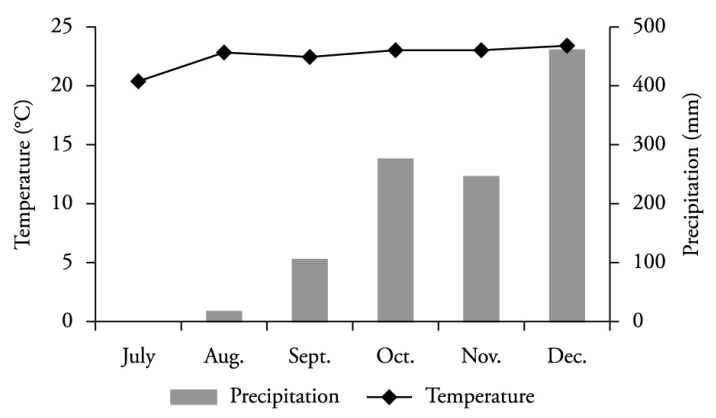

Figure 2. Average temperature $\left({ }^{\circ} \mathrm{C}\right)$ and average total precipitation $(\mathrm{mm})$ of the second half of 2006, recorded monthly in Uberlândia (MG) by Universidade Federal de Uberlândia Climatological Station.
$\mathrm{pH}$ ranged from 5.47 to 6.96 and in Lake II, from 6.12 to 6.93 , but the differences between lakes was not significant. Electrical conductivity was the most varied environmental parameter and the highest values were recorded in Lake I (77.0 mV; Sep B).

The biological community of the two lakes was represented by 75 zooplankton species (Table 1). From these, 57 were rotifers (75\%), 13 cladocerans (18\%) and five copepods (7\%). The rotifers were distributed in 15 families, with Lecanidae as the most representative (18 species). Three families of cladocerans were observed, emphasizing Chydoridae (11 species). Among copepods, only two families and five species were recorded, with four species belonging to Cyclopidae (Cyclopoida). Calanoida was not found in this study. Five different species were added to the list by analyzing the qualitative samples (marked with asterisk in Table 1).

Lake I showed a richness of 66 species compared to only 18 species in Lake II (Table 1). According to richness estimation (Figure 3), the number of samples was very close to stabilization. In both lakes, rotifers strongly prevailed, followed by copepods and cladocerans. Nauplii contributed substantially to the density of copepods in both lakes. In Lake I, 51 species were Rotifera (79\%), 10 were Cladocera (14\%) and five were Copepoda (7\%). Richness also varied temporally from 15 (Aug A) to 36 (Nov A and $\operatorname{Dec} A$ ) species. The dominant species were the rotifers Lecane clara (Lecanidae), Notommata tripus (Notommatidae) and Lecane lunaris (Lecanidae) and a temporal succession between them occurred in the study period. Despite the dominance of these three species, there was a relative uniformity between abundances in Lake I, since total density of rotifers was 50,000 ind. $\mathrm{m}^{-3}$ and that of cladocerans and copepods was about 3,000 ind. $\mathrm{m}^{-3}$ and 5,000 ind. $\mathrm{m}^{-3}$, respectively (Figure 4). Ephemeroporus hibridus (Chydoridae) dominated among cladocerans and Paracyclops fimbriatus (Cyclopidae), among copepods. An exchange of dominance of these species also occurred between Alonella dadayi and Alona ossiani (Chydoridae), and between Ectocyclops strenzkei and Thermocyclops minutus (Cyclopidae), among copepods. In Lake II, 13 species of Rotifera were collected $(72 \%)$, two of Cladocera $(11 \%)$ and three of Copepoda (17\%). The dominant species were also rotifers: Anuraeopsis fissa fissa, Ptygura libera, Polyarthra vulgaris and Trichocerca pusilla. Among cladocerans, Bosminopsis deitersi (Bosminidae) predominated and, among copepods, Paracyclops fimbriatus. In Lake II, there was a clear seasonal alternation. Anuraeopsis fissa fissa reached 
Table 1. Species list of zooplankton from Clube Caça e Pesca Itororó de Uberlândia, Minas Gerais (2006).

\begin{tabular}{|c|c|}
\hline PHYLLUM ROTIFERA & Lepadella rhomboides (Gosse, 1886) “' \\
\hline Classe Bdelloidea & Família Notommatidae \\
\hline Ordem Bdelloida & Cephalodella gibba (Ehrenberg, 1838)' \\
\hline Família Philodinidae & Cephalodella remanei Wiszniewski, 1934 . ' \\
\hline Philodina sp.' & Cephalodella sp.' \\
\hline Classe Monogononta & Monommata cf. arndti Remane, $1933 \bullet$ घ; II \\
\hline Ordem Collothecaceae & Notommata tripus Ehrenberg, $1830 \bullet$ घ; \\
\hline Família Collothecidae & Família Proalidae \\
\hline Collotheca cf. ambigua (Hudson, 1883) a " & Proales brevipes Harring and Myers, 1924 • I \\
\hline Ordem Flosculariaceae & Proales sp. $\bullet 1$ \\
\hline Família Testudinellidae & Proalinopsis caudatus (Collins, 1873) • ם । \\
\hline Testudinella patina (Herman, 1783) • घ; " & Família Trichotriidae \\
\hline Família Flosculariidae & Macrochaetus collinsi (Gosse, 1867)' \\
\hline Ptygura libera Myers, 1934 " & Família Trichocercidae \\
\hline Ptygura cf. pedunculata Edmondson, 1939 - " & Trichocerca cavia (Gosse, 1886) ' \\
\hline Ordem Ploima & Trichocerca cylindrica (Imhof, 1891) I;॥ \\
\hline Família Asplanchnidae & Trichocerca montana Hauer, 1956 - \\
\hline Asplanchna cf. brightwelli Gosse, $1850^{*}$ & Irichocerca obtusidens (Olofsson, 1918) \\
\hline Asplanchna cf. priodonta (Gosse, 1850) a I; II & Trichocerca obtusidens (Olofsson, 1918) - I \\
\hline Família Brachionidae & Trichocerca pusilla (Lauterborn, 1898) I; "I \\
\hline Anuraeopsis fissa fissa (Gosse, 1851) & Trichocerca similis (Wierzejski, 1893) ' \\
\hline Keratella americana Carlin, $1943^{\prime}$ & Trichocerca vargai Wulfert, 1961 . ' \\
\hline Keratella crassa Ahlstrom, 1943 . ' & Família Synchaetidae \\
\hline $\begin{array}{l}\text { Keratella crassa Anistrom, } 1943 \\
\text { Squatinella mutica (Ehrenberg, } 1832\end{array}$ & Polyarthra vulgaris Carlin, 1943 " \\
\hline Família Colurellidae & Synchaeta cf. oblonga Ehrenberg, $1832 \bullet$ —' \\
\hline & PHYLLUM ARTHROPODA \\
\hline Colurella uncinata (O. F. Müller, 1 & Subfilo Crustacea \\
\hline Família Epiphanidae & Classe Branchiopoda \\
\hline Epiphanes cf. clavulata (Ehrenberg, 1832)* & Ordem Cladocera \\
\hline $\begin{array}{l}\text { Epıphanes cr. Clavulata (Enrenberg, 1832)” } \\
\text { Família Euchlanidae }\end{array}$ & Família Bosminidae \\
\hline $\begin{array}{l}\text { Familia Euchlanidae } \\
\text { Beauchampiella eudactylc }\end{array}$ & Bosminopsis deitersi Richard, 1895 ; ॥ \\
\hline $\begin{array}{l}\text { Beauchampiella eudactylc } \\
\text { Euchlanis dilatata Ehrenb }\end{array}$ & Família Chydoridae \\
\hline $\begin{array}{l}\text { Euchlanis dilatata Ehrenberg, } 1832 \\
\text { Euchlanis triquetra Ehrenberg, } 1838 \text {-' }\end{array}$ & Camptocercu tupinamba Sinev and Elmoor-Loureiro, 2010 ' \\
\hline $\begin{array}{l}\text { Euchlanis triquetra Ehrenberg, } 1838 \text {-' } \\
\text { Família Lecanidae }\end{array}$ & Alona ossiani Sinev, 1998 a l; II \\
\hline $\begin{array}{l}\text { Familia Lecanidae } \\
\text { Lecane bulla styrax (Harring and Myers, 1926) }\end{array}$ & Alona cf. intermedia Sars, $1862^{*}$ \\
\hline $\begin{array}{l}\text { Lecane bulla styrax (Harring and Myers, 1926) } \\
\text { Lecane clara (Bryce, 1892)। }\end{array}$ & Alonella dadayi Birge, $1910^{\prime}$ \\
\hline $\begin{array}{l}\text { Lecane clara (Bryce, 1892) } \\
\text { Lecane crepida (Harring, 1914)' }\end{array}$ & Camptocercus australis Sars, $1896^{*} \bullet \mathbf{I}^{\prime}$ \\
\hline $\begin{array}{l}\text { Lecane creplda (Harring, 1914)' } \\
\text { Lecane decipiens (Murray, 1913)। }\end{array}$ & Chydorus eurynotus Sars, 1901 ' \\
\hline $\begin{array}{l}\text { Lecane decipiens (Murray, 1913)' } \\
\text { Lecane flexilis (Gosse, 1889) ' }\end{array}$ & Chydorus cf. sphaericus (O. F. Müller, 1785)* । \\
\hline $\begin{array}{l}\text { Lecane flexilis (Gosse, 1889) } \\
\text { Lecane furcata (Murray, 1913)। }\end{array}$ & Ephemeroporus hibridus (Daday, 1905) • घ' \\
\hline & Leydigiopsis curvirostris Sars, $1901 \bullet$ • ' \\
\hline $\begin{array}{l}\text { Lecane halıclysta Harring and Myers, } 192 \\
\text { Lecane hornemanni (Ehrenberg, 1834)' }\end{array}$ & Picripleuroxus similis (Vavra, 1990) • a' \\
\hline $\begin{array}{l}\text { Lecane hornemanni ( } \\
\text { Lecane leontina (Turn }\end{array}$ & Família Macrothricidae \\
\hline $\begin{array}{l}\text { Lecane leontına (I urner, 1892)' } \\
\text { Lecane Iuna (O.F. Müller, 1776)' }\end{array}$ & Macrothrix cf. triserialis Brady, $1886^{\prime}$ \\
\hline $\begin{array}{l}\text { Lecane luna (O.F. Müller, 1776)' } \\
\text { Lecane Iunaris Ehrenberg, } 1832 \text { ।»॥ }\end{array}$ & Macrothrix sp.' \\
\hline $\begin{array}{l}\text { Lecane lunaris Ehrenberg, } 1832 \text {;; II } \\
\text { Lecane lundwigi (Eckstein, 1883)' }\end{array}$ & Classe Maxillipoda \\
\hline $\begin{array}{l}\text { Lecane lundwigi (Eckstein, 1883)' } \\
\text { Lecane monostylla (Daday, 1897)' }\end{array}$ & Subclasse Copepoda \\
\hline $\begin{array}{l}\text { Lecane monostylla (Daday, 1897)' } \\
\text { Lecane nana (Murray, 1913)' }\end{array}$ & Ordem Cyclopoida \\
\hline & Família Cyclopidae \\
\hline $\begin{array}{l}\text { Lecane pygmea (Daday, 1897) } \mathbf{\text { ' }} \\
\text { Lecane pyriformis (Daday, 1905)' }\end{array}$ & Ectocyclops strenzkei Herbst, 1959 • a \\
\hline $\begin{array}{l}\text { Lecane pyriformis (Daday, 1905)' } \\
\text { Lecane quadridentata (Ehrenberq } 1832\end{array}$ & Mesocyclops longisetus (Thiebaud, 1914) I; " \\
\hline Lecane quadridentata (Ehrenberg, 1832) & Paracyclops fimbriatus Fisher, 1853 ı; ॥ \\
\hline Lecane sp.' & Thermocyclops minutus Lowndes, 1934 । \\
\hline Família Lepadellidae & Ordem Harpacticoida \\
\hline Lepadella astacicola Hauer, 1926 n ' & Família Canthocamptidae \\
\hline Lepadella cristata (Rousselet, 1893)' & Attheyella fuhrmani (Thiebaud, 1914) • घ; " \\
\hline Lepadella imbricata Harring, 1914 -' & 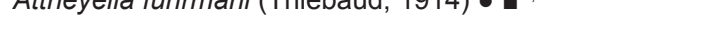 \\
\hline
\end{tabular}

${ }^{\text {I }}$ present in Lake I; ${ }^{\text {II }}$ present in Lake II. ${ }^{*}$ present only in qualitative samples. $\bullet$ new genera recorded for Minas Gerais. new species recorded for Minas Gerais. new sub-species recorded for Minas Gerais. 


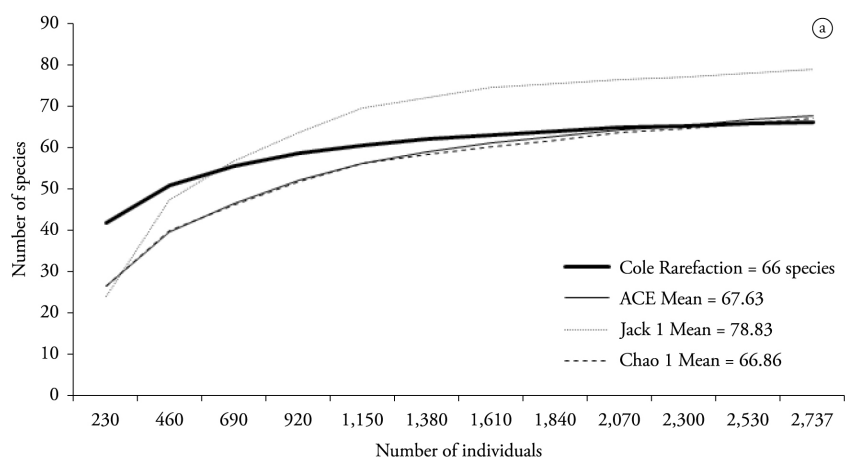

(a)

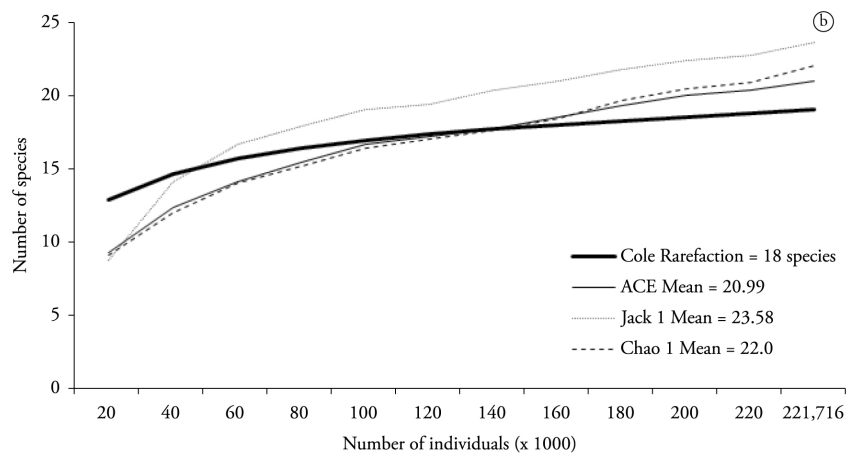

Figure 3. Species accumulation curve (Cole rarefaction) and total richness estimated indexes (ACE mean, Jack 1 mean and Chao 1 mean) of zooplankton from Lake I (a) and Lake II (b) of Clube Caça e Pesca Itororó de Uberlândia, Minas Gerais (2006).
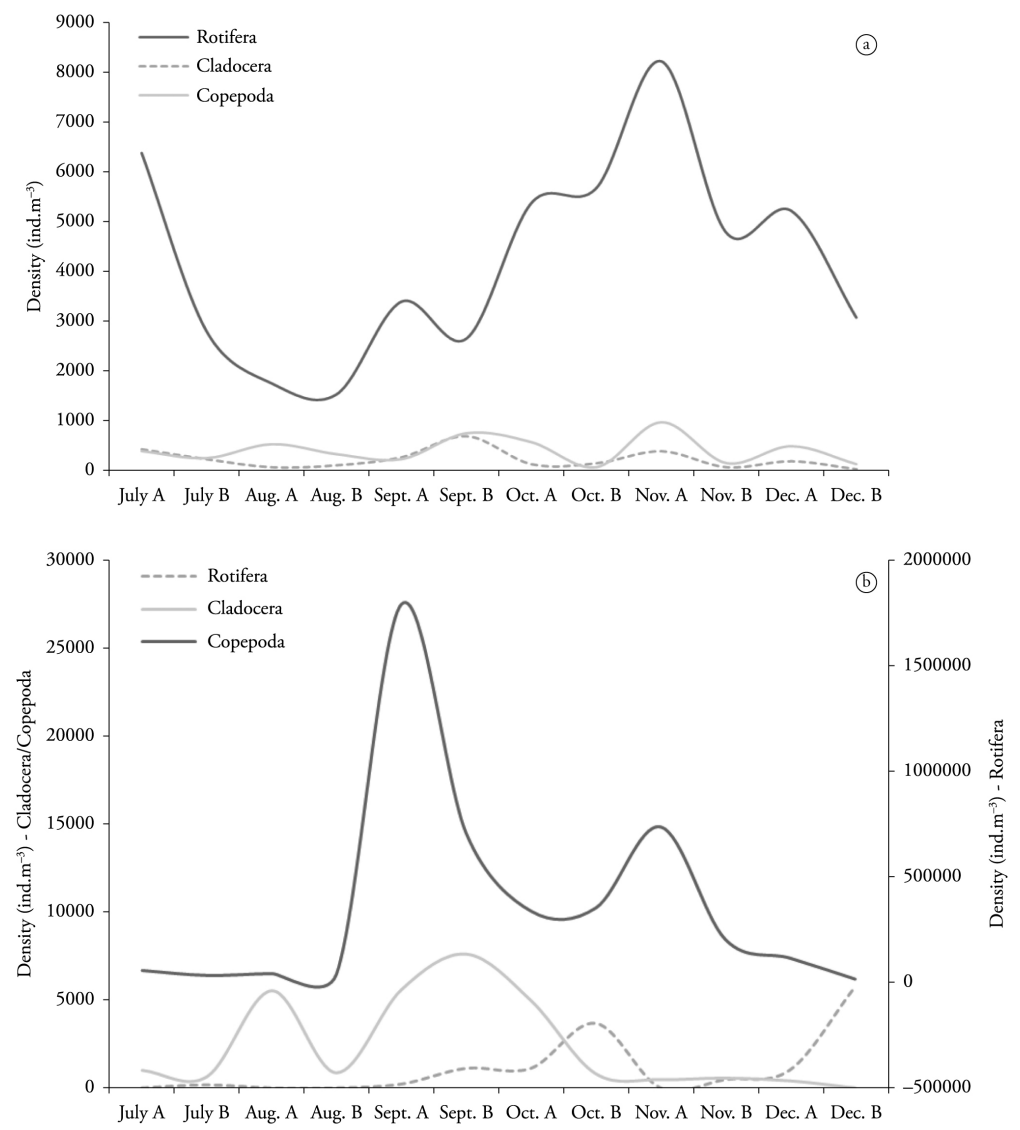

Figure 4. Population fluctuation of zooplankton groups (ind. $\mathrm{m}^{-3}$ ) from Lake I (a) and Lake II (b) in Clube Caça e Pesca Itororó de Uberlândia, Minas Gerais (2006). 
$91 \%$ of relative abundance (Sep A), changing to $87 \%$ of Ptygura libera (Nov A). The occurrence of rotifers was about 4,500,000 ind. $\mathrm{m}^{-3}$. Cladocerans and copepods occurred in considerably lower densities $\left(14,000\right.$ ind. $\mathrm{m}^{-3}$ and 28,000 ind. $\mathrm{m}^{-3}$, respectively) (Figure 4).

Diversity indexes (Shannon-Wiener and Simpson) were different between the lakes $(\mathrm{p}<0.001)$ (Table 2). Richness in the studied area was mainly concentrated on Lake I, but 14 species were common between the environments. Lake I presented 52 exclusive species, but only four species were exclusive of Lake II (Figure 5). However, densities observed in Lake II were higher than in Lake I $(\mathrm{p}<0.05)$. There were no differences in densities between seasons in both lakes ( $p>0.05)$.

Environmental parameters related to biological data through Canonical Correspondence Analysis (CCA) are shown in Figure 6. For Lake I, axis 1 (horizontal variation) reproduces $23.92 \%$ of environmental variability, and axis 2 (vertical variation), $14.75 \%$. Water temperature $(\mathrm{T})$ was the parameter that most contributed horizontally, followed by $\mathrm{pH}(\mathrm{PH})$ and electrical conductivity (C). Dissolved oxygen $\left(\mathrm{O}_{2}\right)$ was the parameter that most affected the vertical variation. There was a large group of species, mainly rotifers, plotted as a function of temperature and, at the same time, against the oxygen. The main species present in this group were Lecane clara (LCL), Lepadella astacicola (LPA), Philodina sp. (PHSP) and Colurella uncinata (CU) among rotifers; Leydigiopsis curvirostris (LEY) among cladocerans and Atheyella furbmani (AF) and Cyclopoida copepodites (CCY) among copepods. Other species such as Lecane lunaris (LLU), Notommata tripus (NT),
Paracyclops fimbriatus (PF), Alonella dadayi (AD), Ephemeroporus hibridus (EH) and nauplii (NA) were placed at intermediate temperature levels and high concentration of oxygen. The $\mathrm{pH}$ affected mainly Ectocyclops strenzkei (ECS), Lecane crepida (LCR) and Proalinopsis caudatus (PC), with occurrence at less acidic $\mathrm{pH}$. Environmental variables explained $50.62 \%$ of the abundance variation ( $\Sigma$ eigenvalues canonical/ non-canonical eigenvalues $\Sigma$ x 100). In Lake II, CCA showed a great relationship between environmental and biological data (64.52\%). Axis 1 reproduces $59.70 \%$ of the environmental variability, indicating high vector significance. Axis 2 explains $3.58 \%$ of the vertical variation. Temperature was also the most strong predictor of the species distribution in Lake II. The most abundant species of the environment, Anuraeopsis fissa fissa (AFF) and Ptygura libera (PL), were placed on opposite regions of the graph, reflecting the alternation of

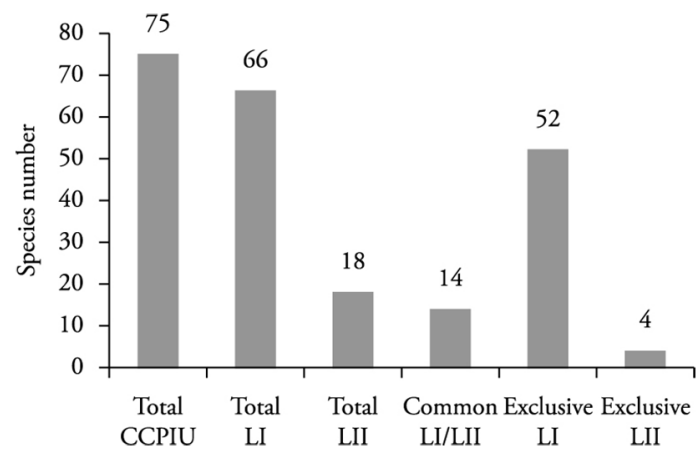

Figure 5. Total, common and exclusive zooplankton species number sampled from each lake in Clube Caça e Pesca Itororó de Uberlândia, Minas Gerais (2006). LI: lake overgrown by macrophytes; LII: open lake.

Table 2. Shannon-Wiener's Diversity $(H)$, Simpson's Diversity $(D)$ and Evenness $(J)$ calculated for zooplankton community of the Lakes I and II of Clube Caça e Pesca Itororó de Uberlândia, Minas Gerais (2006).

\begin{tabular}{|c|c|c|c|c|c|c|}
\hline & \multicolumn{2}{|c|}{$\mathrm{H}^{\prime}$} & \multicolumn{2}{|c|}{ D' } & \multicolumn{2}{|c|}{$J$} \\
\hline & LI & LII & LI & LII & LI & LII \\
\hline July A & 3.636 & 1.330 & 0.901 & 0.557 & 0.841 & 0.573 \\
\hline July B & 3.867 & 1.744 & 0.913 & 0.664 & 0.895 & 0.550 \\
\hline Aug A & 3.162 & 1.855 & 0.847 & 0.692 & 0.809 & 0.661 \\
\hline Aug B & 3.572 & 1.529 & 0.899 & 0.569 & 0.893 & 0.545 \\
\hline Sept A & 3.781 & 0.572 & 0.903 & 0.158 & 0.848 & 0.155 \\
\hline Sept B & 4.007 & 1.088 & 0.917 & 0.330 & 0.853 & 0.343 \\
\hline Oct A & 3.406 & 1.447 & 0.824 & 0.538 & 0.764 & 0.482 \\
\hline Oct B & 3.319 & 1.147 & 0.848 & 0.420 & 0.756 & 0.382 \\
\hline Nov A & 4.165 & 0.772 & 0.907 & 0.233 & 0.806 & 0.244 \\
\hline Nov B & 4.052 & 1.072 & 0.890 & 0.371 & 0.803 & 0.323 \\
\hline $\operatorname{Dec} A$ & 4.461 & 1.421 & 0.938 & 0.478 & 0.863 & 0.448 \\
\hline Dec B & 4.063 & 2.407 & 0.921 & 0.769 & 0.855 & 0.759 \\
\hline Total & 4.449 & 1.467 & 0.940 & 0.544 & 0.736 & 0.345 \\
\hline
\end{tabular}



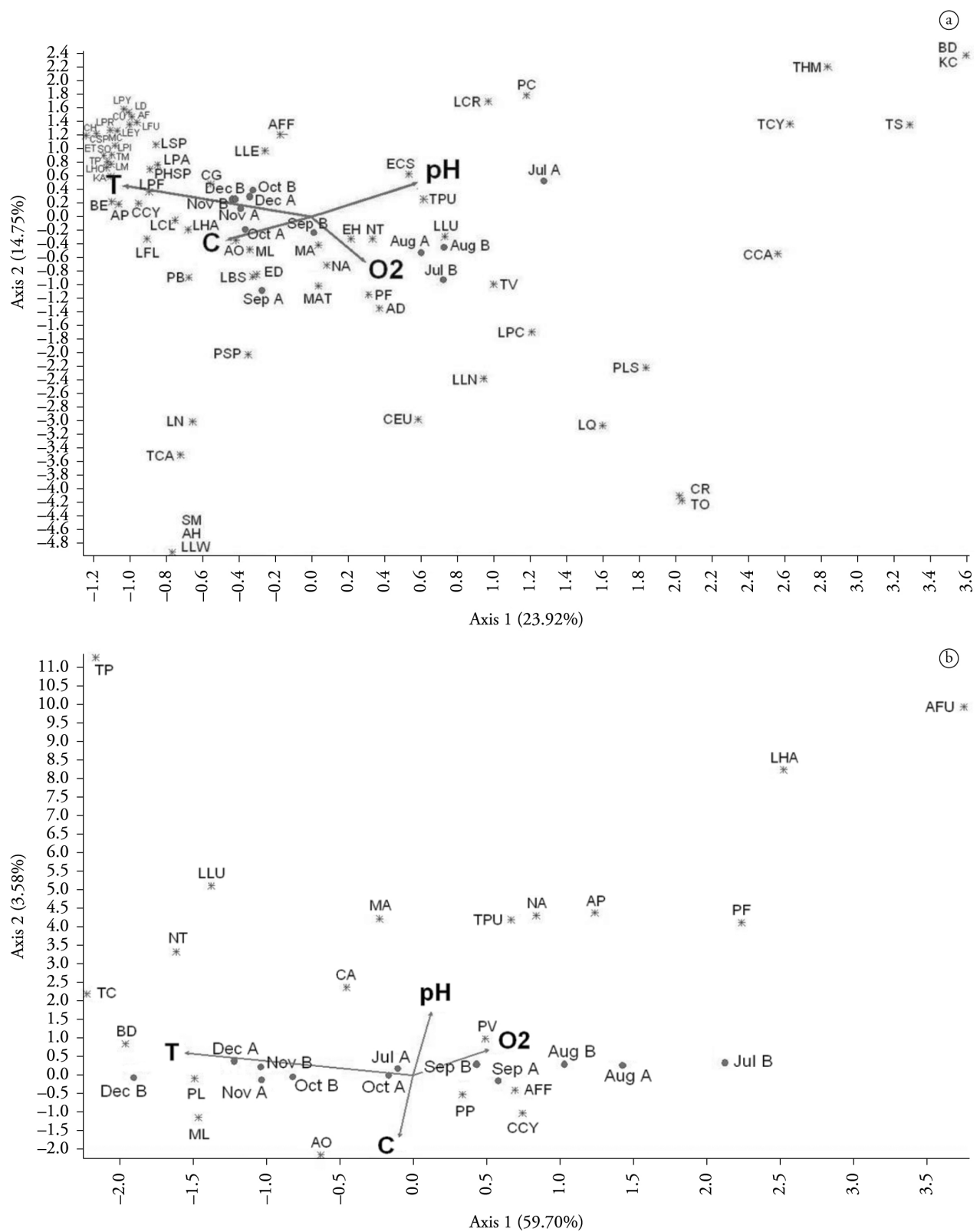

Figure 6. Canonical Correspondence Analysis (CCA) of zooplankton species abundance and samples of Lake I (a) and Lake II (b) from Clube Caça e Pesca Itororó de Uberlândia, Minas Gerais (2006). Circles: samples; asterisks: species; vectors: magnitude and direction of the increment of environmental variables. Abbreviations: $\mathrm{AD}$-Alonella dadayi; AF-Attheyella fuhrmani; AFF-Anuraeopsis fissa fissa; AH-Acroperus tupinamba; AO-Alona ossiani; AP-Asplanchna cf. priodonta; $\mathrm{BD}-$ Bosminopsis deitersi; BE-Beauchampiella eudactylota; CA-Collotheca cf. ambigua; CCY-Cyclopoida copepodites; CEU-Chydorus eurynotus; CG-Cephalodella gibba; CH-Colurella cf. hindenburgi; CR-Cephalodella remanei; CSP-Cephalodella sp.; CU-Colurella uncinata; ECS-Ectocyclops strenzkei; ED-Euchlanis dilatata; EH-Ephemeroporus hibridus; ET-Euchlanis triquetra; KA-Keratella Americana; KC-Keratella crassa; LBS-Lecane bulla styrax; LCL-Lecane clara; LCR-Lecane crepida; LD-Lecane decipiens; LEY-Leydigiopsis curvirostris; LFL-Lecane flexilis; LFU-Lecane furcate; LHA-Lecane haliclysta; LHO-Lecane hornemanni; LLE-Lecane leontina; LLN-Lecane luna; LLU-Lecane lunaris; LLW-Lecane lundwigi; LM-Lecane monostylla; LN-Lecane nana; LPA-Lepadella astacicola; LPC-Lepadella cristata; LPF-Lecane pyriformis; LPI-Lepadella imbricata; LPR-Lepadella rhomboids; LPY-Lecane pygmea; LQ-Lecane quadridentata; LSP-Lecane sp.; MA-Monommata cf. arndti; MASP-Macrothrix sp.; MAT-Macrothrix cf. triserialis; MC-Macrochaetus collinsi; ML-Mesocyclops longisetus; NA-Nauplii; NT-Notommata tripus; PB-Proales brevipes; PC-Proalinopsis caudatus; PF-Paracyclops fimbriatus; PHSP-Philodina sp; PL-Ptygura libera; PLS-Picripleuroxus similis; PP-Ptygura cf. pedunculata; PSP-Proales sp.; PV-Polyarthra vulgaris; SM-Squatinella mutica; SO-Synchaeta cf. oblonga; TCA-Trichocerca cavia; TCY-Trichocerca cylindrical; THM-Thermocyclops minutus; TM-Trichocerca montana; TO-Trichocerca obtusidens; TP-Testudinella patina; TPU-Trichocerca pusilla; TS-Trichocerca similis; TV-Trichocerca vargai. 


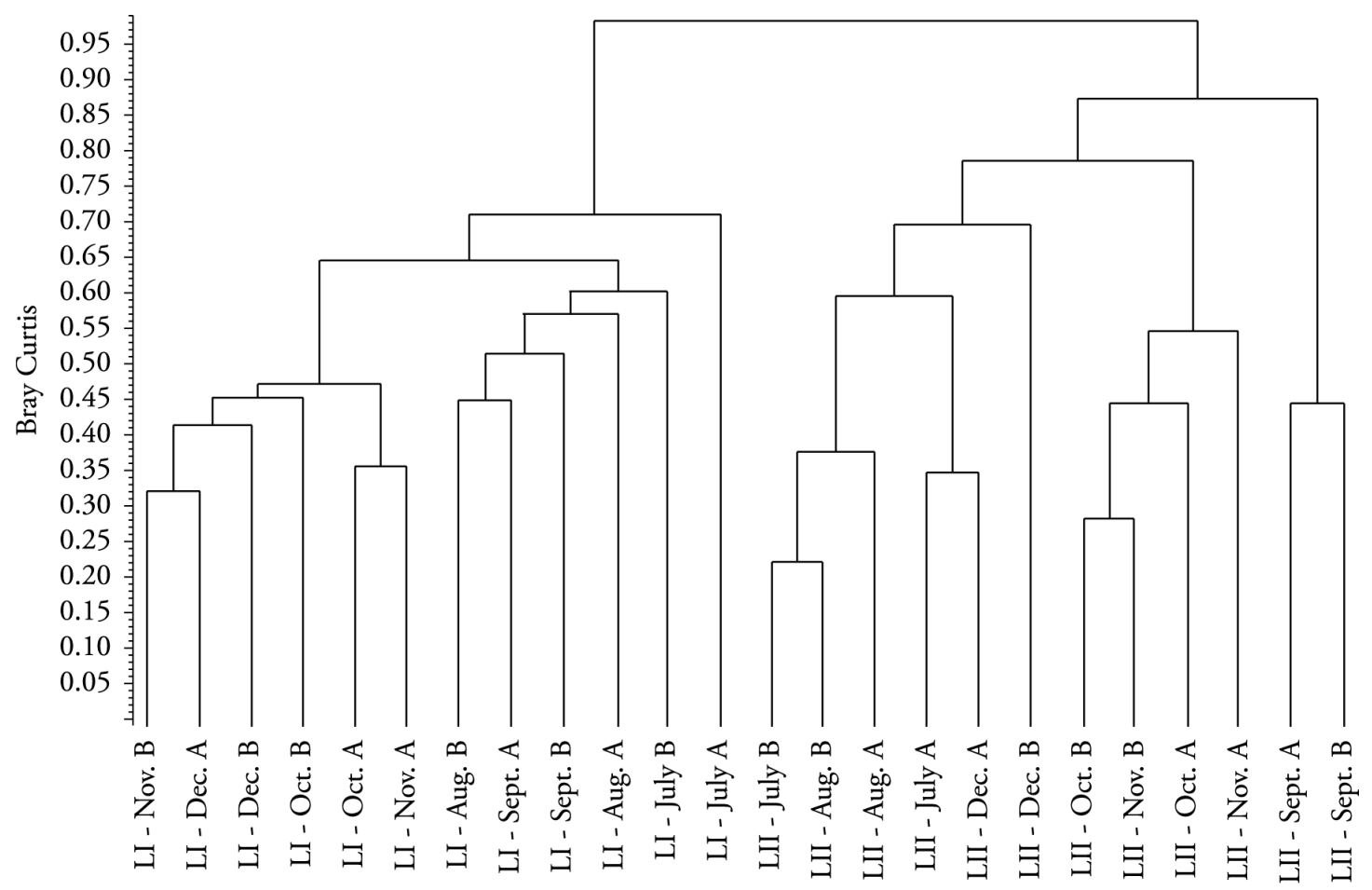

Figure 7. Dendrogram generated from Cluster Analysis for zooplankton abundance data from Clube Caça e Pesca Itororó de Uberlândia, Minas Gerais (2006) using Bray Curtis index and average linkage group (UPGMA). LI: lake overgrown by macrophytes; LII: open lake.

dominance observed between them along the study period. Ptygura vulgaris (PV), Trichocerca pusilla (TPU), nauplii (NA) and Cyclopoida copepodites (CCY) preferred cooler waters. Bosminopsis deitersi (Cladocera) was strongly correlated with high temperature. Despite only 14 species in common, most of them displayed the same environmental preferences independently of the lake.

The cluster dendogram (Figure 7) clearly showed two distinct groups of samples, Lake I and Lake II, and generated groups of samples by season (rainy/dry), isolating "Jul A" by the remarkable presence of Trichocerca similis. Three groups were constructed for Lake II: one formed by samples of September, with predominance of Anuraeopsis fissa fissa; another composed by samples of October and November, with predominance of Ptygura libera; and a third group formed by the samples of July, August and December, which had the lowest total densities. The cofenetic correlation coefficient showed high reliability of the graphics generated (93.91\%).

\section{Discussion}

Particulate sediments like inorganic or organic matter and suspended microorganisms are the most responsible factors for the variation in water transparency. In Lake I, absorption of nutrients into macrophytes, forming a perennial biomass, reduces mineral availability, especially nitrogen and phosphorus, and as a result, limits phytoplankton reproduction. This fact explains the higher transparency in lakes with macrophytes, as well as the lower plankton biomass found in the Lake I.

Many researchers have found strong relationship between temperature and zooplankton composition, both quantitatively and qualitatively (Galkovskaja, 1987; Moore et al., 1996; Rodriguez \& MatsumuraTundisi, 2000; Pinese et al., 2008. The significant difference of temperature between the studied lakes is consider an important ecological variation for aquatic invertebrates. The lowest temperatures observed in Lake I can also be related to macrophytes, which promote shading and remove suspended sediments that absorb solar radiation and heat (Esteves, 2011). However, Margalef (1982) warns that the concepts of succession and annual cycle of plankton should be separated from this great dependence on changes in temperature, because these processes among the planktonic species are difficult to systematize due to the variety of interactions involved. In Lake II, the concentration of free suspended particles is higher, and thus the greater capture of solar energy increases the water 
temperature significantly. This tendency is associated with the loss of oxygen dissolution capacity in high temperatures. In addition, continental water bodies generally have $\mathrm{pH}$ ranging between 6.00 and 8.00 (Schäfer, 1984). As changes in $\mathrm{pH}$ are related to decomposition processes and photosynthetic activities (Esteves, 2011), the high occurrence of zooplanktonic organisms in November may have caused this reduction of $\mathrm{pH}$ to 5.47 (Lake I).

The relationship between seasonal temperature and rainfall cycle with biological conditions is reflected in shifts of resource availability, species behavior and physiological factors, changing also population attributes such as richness and abundance (Margalef, 1982). The biological richness in ponds is based on these processes, operating in spatial and temporal scale (Brönmark and Hansson, 2005). Studies in several lakes in the state of Minas Gerais have shown an average richness of 35 zooplankton species (Eskinazi-Sant'Anna et al., 2005). However, the richness found in this study was about two times higher than this number. Furthermore, among the biodiversity herein found, 12 genera, 29 species and one sub-species represented the first record for Minas Gerais (Table 1). These new records can be attributed to the fact that most research conducted in Minas Gerais so far was concentrated in the São Francisco, Doce and Grande River Basins. The contribution to the local zooplankton diversity was mainly due to the rotifers. In tropical lakes, the rotifer predominance has been a rule (Matsumura-Tundisi, 1999). According to this autor, the unstable hydrodynamic operation of artificial lakes, with frequent disturbances, favors opportunistic $r$-strategist species with short life cycles that invest in numerous offsprings. In the case of zooplankton, these organisms are represented by the rotifers. Therefore, in new and unstable systems, the richness becomes higher mostly due to this group. According to Rocha et al. (1995), rotifers predominate in Brazilian lentic systems in density too. Brönmark \& Hansson (2005) argue that rotifers are an important group in aquatic ecosystems, especially because they present in addition to the high reproductive capacity, the ability to occupy different niches in a short space of time, thus reaching very high densities. Therefore, niche partitioning is a strategy that exerts strong influence on this group (Sampaio et al., 2002).

This study also showed low richness of copepods (five species) in both lakes, but the high abundance observed in some samples was mainly due to juvenile stages, unlike expected, since this group frequently occurs in lakes with macrophytes
(Matsumura-Tundisi, 1999). Studies have recorded that different stages of copepods live in separated regions in water column as an attempt to avoid life-stage competition, and this migration behavior can also occur in freshwater lakes (Nogueira \& Panarelli, 1997). This fact may have restricted the sample of adults in this study. Another possible explanation is that the copepod development is being limited by the short pulses of the environment (low retention time), considering that these animals have higher life-cycle comparing to another planktonic organisms (Santos-Wisniewski \& Rocha, 2007).

According to the qualitative aspects, typical species of littoral zone occurred mainly in the lake with macrophytes (Lake I), what can be explained by the lake morphological characteristics. The richest family was Lecanidae, which is frequently reported in lakes overgrown by macrophytes (Starling, 2000; Santos-Wisniewski et al., 2002). Chydoridae and Trichocercidae also figured among the most important families, and among copepods, Cyclopidae was the most representative family, all associated with littoral zone. Among typical limnetic species, Bosminopsis deitersi (Bosminidae) occurred preferentially in the open lake (Lake II). According to Arcifa (1984), this is a common zooplankton species in Brazilian reservoirs.

An ecological succession in a lake can be studied through abundance and seasonal changes on composition of plankton species (Giani \& Figueiredo, 1999). Once zooplankton has fast renewal rates, the temporal proximity of samples allowed a less fragmented analysis of the populations (Esteves, 2011). Fluctuation graphs show temporal variations between population groups, and the dominant species were the most responsible for designing the patterns observed. In the case of Lake I, Lecane clara, Notommata tripus and Lecane lunaris substantially affected fluctuations of Rotifera. There was a clear seasonal pattern between populations, with higher density of Lecane clara during rainy season, and the other two populations during dry season. Cladocerans and copepods presented cyclical pattern densities of seasonal fluctuations, and these populations can self-regulate. The cladocerans were mainly affected by Ephemeroporus hibridus, Alona dadayi and Alonella ossiani, and for copepods, mainly nauplii and Paracyclops fimbriatus affected the graphic design. For Lake II, a similar situation happened among the groups, since Rotifers showed seasonality, and cladocerans and copepods showed cyclical patterns. 
Despite alternation of dominant species do not occur frequently among rotifers in tropical lakes (Matsumura-Tundisi and Tundisi, 1976; Matsumura-Tundisi et al., 1990; Sampaio et al., 2002), this situation was evident in the studied lakes. It can be understood as a coexistence strategy, and this notion refers to the classic article of Hutchinson (1961) about "the paradox of the plankton." In other words, the large number of species occurring in most planktonic communities do not support the competitive exclusion principle. According to Hutchinson (1961), the planktonic populations exhibit great diversity because they always fail to achieve the equilibrium, then their populations fluctuate chaotically. However, this lack of standard and these apparently chaotic fluctuations may in fact represent an evolutionary adaptation. Even today, little was added to the Hutchinson's theory due to the complexity that surrounds the plankton dynamics (Scheffer et al., 2003).

There was a clear variation in diversity and densities between the lakes, despite their physical connection. In relation to richness, the lake with macrophytes had an advantage, but in relation to abundance, the open lake excelled. These results could be explained by the transference of energy within the environment and by the niche diversity, since most water available minerals keep "arrested" for long periods in the macrophyte biomass. Moreover, macrophytes allow the emergence of a variety of niches and microhabitats, supporting a highly diverse zooplankton community around them. On the other hand, the open lake maintains free minerals that can be inserted in the plankton chain, allowing the high densities observed for some species. But richness in this lake was low, reflecting its great spatial uniformity and limitation of niches (Melão et al., 2005).

These results show the importance of different habitats and local environmental conditions favoring survival and reproduction of different species, as proposed by Niche Theory (Grinnell, 1917). Furthermore, the evident difference in abundance between the lakes suggests an energy and biomass deficit in zooplankton community in the lake with macrophytes. Once abundance can reflect a secondary productivity, i.e. the production generated by filtering or "pasture" of phytoplankton (Melão et al., 2005), this study shows that secondary productivity tends to be lower in environments overgrown by macrophytes.

Anuraeopsis fissa fissa and Trichocerca pusilla were the species that most contributed to increase similarity between the lakes. Despite the high local diversity (alpha diversity) in each lake, the turnover of species was also high. The presented cluster analysis reinforces the ecological difference between the lakes, as seen through the richness and abundance data.

In conclusion, the composition of zooplankton communities in the studied lakes was spatially and temporally determined according to macrophyte banks and to seasonal and environmental parameters of water. Temperature was the most important factor in determining the zooplankton community in both lakes. There was a high turnover of species between the lakes, which differ mainly by high richness and low density of individuals in the small lake overgrown by macrophytes, and lower richness and high density in the open lake. Rotifers predominated in two studied lakes upon cladocera and copepoda, both in richness and density. More studies on zooplankton communities need to be developed in veredas in Brazil, especially in little explored basins. This intention is reinforced by the presence of new genera, species and sub-species recorded for Minas Gerais in the present work. This knowledge emphasizes Brazilian biodiversity and straightens a necessity of conservation in aquatic ecosystems.

Studies like this also demonstrate the significance of investments in primary ecology, mainly on community composition. The new taxonomic records found for the state of Minas Gerais demonstrate that studies on zooplankton communities in the vast Brazilian territory still have much to be explored. Moreover, this study indicates future investigations, such as plankton productivity in different patterns of surface cover, niche partition in zooplankton communities and seasonality versus cyclical regulations. It is suggested higher investment in researches concerning vereda zooplankton in Brazil, since it is known how biological relationships in aquatic ecosystems are fragile, but at the same time, important to sustain a whole diversity of surroundings. The conservation of water reserves in the world is also dependent on the health of these plankton communities that support continental aquatic ecosystem trophic chains. Thereby, natural ecosystems, such as vereda wetlands, must particularly be preserved.

\section{Acknowledgements}

This work was technically supported by the Programa de Pós-Graduação em Ecologia e Conservação de Recursos Naturais da Universidade Federal de Uberlândia. The authors would also like 
to thank Dra. Deise Aparecida de Oliveira Silva and Prof. MSc. Breno Augusto de Oliveira Silva for English review and helpful suggestions; MSc. José Fernando Pinese Júnior, for the development of images and maps; and the anonymous reviewer for their constructive comments, which helped us to improve this manuscript.

\section{References}

APPOLINARIO, V. and SCHIAVINI, I. Levantamento fitossociológico de espécies arbóreas de cerrado (stricto sensu) em Uberlândia - Minas Gerais. Boletim do Herbário Ezechias Paulo Heringer, 2002, 10, 57-75.

ARAÚJO, G.M., BARBOSA, A.A.A., ARANTES, A.A. and AMARAL, A.F. Composiçâo florística de veredas no Município de Uberlândia, MG. Revista Brasileira de Botânica, 2002, 25(4), 475-493. http://dx.doi. org/10.1590/S0100-84042002012000012.

ARCIFA, M.S. Zooplankton composition of ten reservoirs in southern Brazil. Hydrobiologia, 1984, 113(1), 137-145. http://dx.doi.org/10.1007/ BF00026600.

BINI, L.M., OLIVEIRA, L.G., SOUZA, D.C., CARVALHO, P. and PINTO, M.P. Patterns of the aquatic macrophyte cover in Cachoeira Dourada Reservoir (GO-MG). Brazilian Journal of Biology, 2005, 65(1), 19-24. http://dx.doi.org/10.1590/ S1519-69842005000100004. PMid:16025899.

BJÖRK, S. Treatment of overgrown shallow lakes through macrophyte control: the case study of lake Hornborga, Sweden. Wetlands: Ecology, Conservation and Management, 2010, 3, 123-144.

BLACK, A.R. and DODSON, S.I. Ethanol: a better preservation technique for Daphnia. Limnology and Oceanography, Methods, 2003, 1, 45-50. http:// dx.doi.org/10.4319/lom.2011.1.45.

BRÖNMARK, C. and HANSSON, L.A. The biology of lakes and ponds. 2nd ed. Oxford: Oxford University Press, 2005, 285 p.

CASATTI, L., MENDES, H.F. and FERREIRA, K.M. Aquatic macrophytes as feeding site for small fishes in the Rosana Reservoir, Paranapanema River, southeastern Brazil. Brazilian Journal of Biology, 2003, 63(2), 213-222. http://dx.doi.org/10.1590/ S1519-69842003000200006. PMid:14509843.

COLARES, M.A.M., BONECKER, C.C., SIMỐES, N.R., ALVES, G.M. and LANSAC-TÔHA, F.A. Structure of the zooplankton communities in macrophytes stand of a Neotropical floodplain (the Paraná River, Brazil). International Review of Hydrobiology, 2013, 98(2), 89-103. http://dx.doi. org/10.1002/iroh.201301471.

COLWELL, R.K. EstimateS: statistical estimation of species richness and shared species from samples. Version 7.5. User's Guide and application published [online]. 2005. [viewed 11 Dec. 2007]. Available from: http://purl. oclc.org/estimates

DEL-GROSSI, S.R. A dinâmica climática atual de Uberlândia e suas implicações geomorfológicas. Sociedade e Natureza. 1993, 5(9/10), 115-120.

DUSSART, B.H. and DEFAYE, D. Introduction to Copepoda. In H.J. DUMONT, coord. Guides to the identification of the microinvertebrates of the continental waters of the world. Amsterdam: SPB Academic Publishing, 1995, $277 \mathrm{p}$.

ELMOOR-LOUREIRO, L.M.A. Manualde identificação de cladóceros límnicos do Brasil. Brasília: Editora Universa, 1997, $155 \mathrm{p}$.

ESKINAZI-SANT'ANNA, E.M., MAIA-BARBOSA, P.M., BRITO, S. and RIETZLER, A.C. Zooplankton biodiversity of Minas Gerais State: a preliminary synthesis of present knowledge. Acta Limnologica Brasiliensia. 2005, 17(2), 199-218.

ESTEVES , F.A. and CAMARGO, A.F.M. Sobre o papel das macrófitas aquáticas na estocagem e ciclagem de nutrientes. Acta limnologica Brasiliensia. 1986, 1, 273-298.

ESTEVES, F.A. Fundamentos de Limnologia. 3rd ed. Rio de Janeiro: Interciência, 2011, 828 p.

GALKOVSKAJA, G.A. Planktonic rotifers and temperature. Hydrobiologia. 1987, 147(1), 289-319.

GIANI, A. and FIGUEIREDO, C.C. Recorrência de padrōes sazonais do fitoplâncton num reservatório eutrófico (Reservatório da Pampulha, MG). In R. HENRY, ed. Ecologia de reservatórios: estrutura, função $e$ aspectos sociais. Botucatu: FUNDIBIO/FAPESP, 1999, p. 531-550.

GRINNELL, J. The niche-relationship of the California thrasher. The Auk, 1917, 34(4), 427-433. http:// dx.doi.org/10.2307/4072271.

HALL, D.J. An experimental approach to the dynamics of a natural population of Daphnia galeata mendotae. Ecology, 1964, 45(1), 94-112. http://dx.doi. org/10.2307/1937111.

HUTCHINSON, G.E. The paradox of the plankton. American Naturalist, 1961, 95(882), 137-145. http:// dx.doi.org/10.1086/282171.

JERSABEK, C.D., SEGERS, H. and MORRIS, P.J. An illustrated online catalog of the Rotifera in the Academy of Natural Sciences of Philadelphia (version 1.0: 2003-April-8) [online]. 2007. [viewed 11 Dec. 2007]. Available from: http://rotifer.ansp.org/rotifer.php

KÖPPEN, W. Climatologia: con un estudio de los climas de la tierra. México: Fondo de Cultura Econômica, 1948, $479 \mathrm{p}$.

KORINEK, V. A guide to limnetic species of Cladocera of African inland Waters (Crustacea, Brachiopoda) (Using the morphology of parthenogenetic females). Alabama: The International Association of Theoretical and Applied Limnology, 1999, 122 p. 
KOROVCHINSKY, N.M. Sididae \& Holopediidae (Crustacea: Daphniiformes). In H.J. DUMONT. Guides to the identification of the microinvertebrates of the continental waters of the world. Ontario: SPB Academic Publishing, 1992, 82 p.

KOSTE, W. Rotatoria: die rädertiere mitteleuropas. Berlin: Gerbrüder Borntraeger, 1978.

LANSAC-TÔHA, F.A., BONECKER, C.C., VELHO, L.F.M., SIMÓES, N.R., DIAS, J.D., ALVES, G.M. and TAKAHASHI, E.M. Biodiversity of zooplankton communities in the Upper Paraná River floodplain: interannual variation from long-term studies. Brazilian Journal of Biology, 2009, 69(2), 539-549. Supplement. http://dx.doi.org/10.1590/ S1519-69842009000300009. PMid:19738961.

LIMA, A.F., LANSAC-TÔHA, F.A., VELHO, L.F.M., BINI, L.M. and TAKEDA, A.M. Composition and abundance of Cladocera (Crustacea) assemblages associated with Eichhornia azurea (Swartz) Kunth stands in the Upper Paraná River floodplain. Acta Scientiarum. Biological Sciences, 2003, 25(1), 41-48.

MAIA-BARBOSA, P.M., PEIXOTO, R.S. and GUIMARÃES, A.S. Zooplankton in littoral waters of a tropical lake: a revisited biodiversity. Brazilian Journal of Biology, 2008, 68(4), 1069-1078. Supplement. http://dx.doi.org/10.1590/S151969842008000500014. PMid:19197477.

MARGALEF, R. Ecología. Barcelona: Omega S.A., 1982, $951 \mathrm{p}$.

MATSUMURA-TUNDISI, T. and ROCHA, O. Occurence of Copepod (Calanoida Cyclopoida and Harpacticoida) from "Broa” Reservior (São Carlos, São Paulo, Brazil). Revista Brasileira de Biologia, 1983, 43, 1-17.

MATSUMURA-TUNDISI, T. and TUNDISI, J.G. Plankton studies in a lacustrine environment. I. Preliminary data on zooplankton ecology of Broa Reservoir. Oecologia, 1976, 25(3), 265-270. http:// dx.doi.org/10.1007/BF00345103.

MATSUMURA-TUNDISI, T. Diversidade de zooplâncton em represas do Brasil. In R. HENRY. Ecologia de reservatórios: estrutura, função e aspectos sociais. Botucatu: FUNDIBIO/FAPESP, 1999, p. 39-54.

MATSUMURA-TUNDISI, T. Latitudinal distribution of Calanoida copepods in freshwater aquatic systems of Brazil. Revista Brasileira de Biologia, 1986, 46(3), 527-553.

MATSUMURA-TUNDISI, T., NEUMANN-LEITÃO, S., AGUENA, L.S. and MIYAHARA, J. Eutrofização da represa de Barra Bonita: Estrutura e organização da comunidade de Rotifera. Revista Brasileira de Biologia, 1990, 50(4), 923-935.

MELÃO, M.G.G., ROCHA, O. and ROCHE, K.F. Produtividade, biomassa, flutuaçóes populacionais e interaçóes biológicas da comunidade planctônica e suas implicaçóes na transferência de energia na cadeia alimentar de um reservatório raso e oligotrófico. In K.F. ROCHE and O. ROCHA, orgs. Ecologia trófica de peixes com ênfase na planctivoria em ambientes lênticos de água doce no Brasil. São Carlos: RiMa, 2005, $136 \mathrm{p}$.

MOORE, M.V., FOLT, C.L. and STEMBERGER, R.S. Consequences of elevated temperatures for zooplankton assemblages in temperate lakes. Archiv für Hydrobiologie, 1996, 135(3), 289-319.

MORALES, E.S., REID, J.W., ILIFFE, T.M. and FIERS, F. Catálogo de los copépodos (Crustacea) continentales de la península de Yucatán, México. Chetumal: ECOSUR, 1996, 296 p.

NOGUEIRA, M.G. and PANARELLI, E. Estudo da migração vertical das populaçóes zooplanctônicas na Represa de Jurumirim (Rio Paranapanema-São Paulo, Brasil). Acta Limnologica Brasiliensia, 1997, 9, 55-81.

PEIXOTO, R.S., SÁ, C.E.M., GUIMARÃES, A.S. and MAIA-BARBOSA, P.M. Seasonal fluctuations of the microcrustacean assemblages in the littoral zone of Lake Dom Helvécio (Parque Estadual do Rio Doce, MG). Acta Limnologica Brasiliensia, 2008, 20(3), 213-219.

PIELOU, E.C. Freshwater. Chicago: The University of Chicago Press, 1998, 275 p.

PINESE, O.P., ALMEIDA, C.G., RÊGO, A C.L. and PINESE, J.F. Ecology of a zooplanktonic community in an urban lake in southeastern Brazil (Uberlândia, MG). Revista Brasileira de Zoociências, 2008, 10(2), 105-114.

PINTO-COELHO, R.M. Métodos de coleta, preservação, contagem e determinação de biomassa em zooplâncton de águas epicontinentais. In C.E. M. BICUDO and D.C. BICUDO. Amostragem em limnologia. São Carlos: RiMa, 2004, 351 p.

PONTIN, R.M. A key to British freshwater planktonic Rotifera. Winderemere: Freshwater Biological Association, 1978, 178 p.

REID, J.L.W. Chave de identificação e lista de referências bibliográficas para as espécies continentais sulamericanas de vida livre da ordem Cyclopoida (Crustacea, Copepoda). Boletim de Zoologia. 1985, 9, 17-143.

ROCHA, O. and MATSUMURA-TUNDISI, T. Atlas do zooplâncton: (Represa do Broa, São Carlos). São Carlos: Universidade Federal de Sáo Carlos, 1976, 544 p, vol. 1.

ROCHA, O., SENDACZ, S. and MATSUMURATUNDISI, T. Composition, biomass and productivity of zooplankton in natural lakes and reservoirs in Brazil. In J.G. TUNDISI, C.E.M. BICUDO and T. MATSUMURA-TUNDISI, eds. Limology in Brazil. Rio de Janeiro: ABC/SBL, 1995, pp. 151-166. 
RODRIGUEZ, M.P. and MATSUMURA-TUNDISI,

T. Variation of density, species composition and dominance of rotifers at a shallow tropical reservoir (Broa Reservoir, SP, Brazil) in a short scale time. Revista Brasileira de Biologia, 2000, 60(1), 1-9. http:// dx.doi.org/10.1590/S0034-71082000000100002. PMid: 10838918.

SAMPAIO, E.V., ROCHA, O., MATSUMURATUNDISI, T. and TUNDISI, J.G. Composition and abundance of zooplankton in the limnetic zone of seven reservoirs of the Paranapanema river, Brazil. Brazilian Journal of Biology, 2002, 62(3), 525-545. http://dx.doi.org/10.1590/S151969842002000300018. PMid:12530191.

SANTOS-WISNIEWSKI, M.J. and ROCHA, O. Spatial distribution and secondary production of Copepoda in a tropical reservoir: Barra Bonita, SP, Brazil. Brazilian Journal of Biology, 2007, 67(2), 223-233. http://dx.doi.org/10.1590/S151969842007000200007. PMid:17876432.

SANTOS-WISNIEWSKI, M.J., ROCHA, O., GÜNTZEL, A.M. and MATSUMURA-TUNDISI, T. Cladocera Chydoridae of high altitude water bodies (Serra da Mantiqueira), in Brazil. Brazilian Journal of Biology, 2002, 62(4A), 1-11. http:// dx.doi.org/10.1590/S1519-69842002000400016. PMid:12659018.

SCHÄFER, A. Fundamentos de ecologia e biogeografia das águas continentais. Porto Alegre: Ed. da Universidade UFRGS, 1984, $532 \mathrm{p}$.

SCHEFFER, M., RINALDI, S., HUISMAN, J. and WEISSING, F.J. Why plankton communities have no equilibrium: solutions to the paradox. Hydrobiologia, 2003, 490(1-3), 9-18. http://dx.doi. org/10.1023/A:1024404804748.

SEGERS, H. Rotifera: the Lecanidae (Monogononta). In H.J. DUMONT, coord. Guides to the identification of the microinvertebrates of the continental waters of the world. Ontario: SPB Academic Publishing, 1995, 226 p., vol. 2.

SHEPHERD, G.J. Fitopac 1.6: manual de usuário. Campinas: Unicamp, 1996.

SILVA, E.N.S., ROBERTSON, B.A., REID, J L.W. and HARDY, E.R. Atlas de copépodos planctônicos, Calanoida e Cyclopoida (Crustacea), da Amazônia Brasileira: Represa de Curuá-Uma, Pará. Revista Brasileira de Zoologia, 1989, 6(4), 725-758. http:// dx.doi.org/10.1590/S0101-81751989000400019.
SINEV, A.Y. and ELMOOR-LOUREIRO, L.M.A. Three new species of chydorid cladocerans of subfamily Aloninae (Branchipoda: Anomopoda: Chydoridae) from Brazil. Zootaxa, 2010, 2390, 1-25.

SMIRNOV, N.N. A revision of the genus Camptocercus (Anomopoda, Chydoridae, Aloninae). Hydrobiologia, 1998, 386(1/3), 63-83. http://dx.doi. org/10.1023/A:1003524414799.

SMIRNOV, N.N. Cladocera: The Chydorinae and Sayciinae (Chydoridae) of the world. In H.J. DUMONT, coord. Guides to the identification of the microinvertebrates of the continental waters of the world. Ontario: SPB Academic Publishing, 1996, 197 p.

STARLING, F. L. do R. M. Comparative study of the zooplankton composition of six lacustrine ecosystems in Central Brazil during the dry season. Revista Brasileira de Biologia, 2000, 60(1), 101-111. http:// dx.doi.org/10.1590/S0034-71082000000100013. PMid:10838929.

SYSTAT. Systat Software Inc. (SSI) Version 10.2. California, 2002.

TANIGUCHI, G.M., BICUDO, D.C. and SENNA, P.A.C. Gradiente litorâneo-limnético do fitoplâncton e ficoperifíton em uma lagoa da planície de inundação do Rio Mogi-Guaçu. Revista Brasileira de Botanica. Brazilian Journal of Botany, 2005, 28(1), 137-147. http://dx.doi.org/10.1590/S010084042005000100011.

TER-BRAAK, C.J.F. CANOCO - a FORTRAN program for canonical community ordination by (partial) (detrended) (canonical) correspondence analysis, principal components analysis and redundancy analysis (Version 2.1). Wageningen: Institute of Applied Computer Science, 1988, 95 p., Technical Report LWA-88-02, TNO.

TER-BRAAK, C.J.F. Canonical correspondence analysis: a new eigenvector technique for multivariate direct gradient analysis. Ecology, 1986, 67(5), 1167-1179. http://dx.doi.org/10.2307/1938672.

TER-BRAAK, C.J.F. Ordination. In R.H.G. JONGMAN, C J.F. TER-BRAAK and O.F.R. VANTONGEREN, eds. Data analysis in community and landscape ecology. Cambridge: Cambridge University, 1995, pp. 91-173.

ZAR J.H. Biostatistical analysis. 3rd ed. New Jersey: Prentice Hall, 1999, 662 p.

Received: 10 February 2015 Accepted: 03 September 2015 